\title{
Emendation of the Genus Acetivibrio and Description of Acetivibrio cellulosolvens sp. nov., a Nonmotile Cellulolytic Mesophile $\dagger$
}

\author{
A. W. KHAN,* ERIN MEEK, L. C. SOWDEN, AND J. ROSS COLVIN \\ Division of Biological Sciences, National Research Council of Canada, Ottawa, Ontario, Canada KlA OR6
}

\begin{abstract}
The genus Acetivibrio is emended to include nonmotile, gram-negative, obligately anaerobic rods that produce acetic acid and ethanol from fermentation of carbohydrates. A new species, Acetivibrio cellulosolvens, which was isolated from a cellulose-enriched culture of sludge, is described. The colonies on agar are entire, raised, and cream colored. The cells are straight rods, gram-negative, nonsporeforming, and nonmotile. The isolate which we studied ferments cellobiose, cellulose, esculin, and salicin and does not require yeast extract or rumen fluid for growth. The major end products produced from cellobiose or cellulose are acetic acid, ethanol, $\mathrm{CO}_{2}$, and $\mathrm{H}_{2}$. Lactic acid and glucose also are produced in small amounts. The type strain of $A$. cellulosolvens is strains BAS (= NRC 2936).
\end{abstract}

A cellulolytic anaerobe that was isolated from a heattreated, cellulose-enriched culture (8) started from sewage sludge is described. This nonsporeforming, mesophilic, rodshaped anaerobe has the ability to survive heating at $80^{\circ} \mathrm{C}$ for $10 \mathrm{~min}$ in mixed cultures, but not in pure culture. The new isolate is described as Acetivibrio cellulosolvens sp. nov.

\section{MATERIALS AND METHODS}

Media. The basal medium used for isolation and culture maintenance was the same medium that was used for the development of cellulose-enriched cultures (7). This basal medium contained the following components (in milligrams per liter): $\mathrm{NaHCO}_{3}, 2.060 ; \mathrm{NH}_{4} \mathrm{Cl}, 680 ; \mathrm{K}_{2} \mathrm{HPO}_{4}, 296$; $\mathrm{KH}_{2} \mathrm{PO}_{4}, 180 ;\left(\mathrm{NH}_{4}\right)_{2} \mathrm{SO}_{4}, 150 ; \mathrm{MgSO}_{4} \cdot 7 \mathrm{H}_{2} \mathrm{O}, 120$; $\mathrm{CaCl}_{2} \cdot 2 \mathrm{H}_{2} \mathrm{O}, 61 ; \mathrm{FeSO}_{4} \cdot 7 \mathrm{H}_{2} \mathrm{O}, 21 ; \mathrm{N}\left(\mathrm{CH}_{2} \mathrm{COOH}\right)_{3}, 15$; $\mathrm{NaCl}, 10 ; \mathrm{MnSO}_{4} \cdot \mathrm{H}_{2} \mathrm{O}, 5 ; \mathrm{CoCl}_{2} \cdot 6 \mathrm{H}_{2} \mathrm{O}, 1$; $\mathrm{ZnSO}_{4} \cdot 7 \mathrm{H}_{2} \mathrm{O}, 1 ; \mathrm{CuSO}_{4} \cdot 5 \mathrm{H}_{2} \mathrm{O}, 0.1 ; \mathrm{AlK}\left(\mathrm{SO}_{4}\right)_{2} \cdot 12 \mathrm{H}_{2} \mathrm{O}$, $0.1 ; \mathrm{H}_{3} \mathrm{BO}_{4}, 0.1 ; \mathrm{Na}_{2} \mathrm{MoO}_{4} \cdot 2 \mathrm{H}_{2} \mathrm{O}, 0.1$; pyridoxine hydrochloride, 0.1 ; thiamine hydrochloride, 0.05 ; riboflavin, 0.05 ; nicotinic acid, 0.05; $p$-aminobenzoic acid, 0.05; lipoic acid, 0.05 ; biotin, 0.02 ; folic acid, 0.02 ; vitamin $\mathrm{B}_{12}, 0.005$; and resazurin, 1 . This medium was supplemented with cellulose (type CF-11; Whatman) or tissue paper (Kleenex; KimberlyClark of Canada, Ltd.) and with $2 \%$ (wt/vol) agar (Difco Laboratories, Detroit, Mich.) for culture isolation. The $\mathrm{pH}$ of the medium was adjusted to $7.0 \pm 0.2$, and the medium was reduced by using a cysteine-sodium sulfide solution and the Hungate technique (5). A gas mixture containing $80 \% \mathrm{~N}_{2}$ and $20 \% \mathrm{CO}_{2}$ was used as a headspace gas. Usually, 10-ml portions of the prereduced medium were dispensed into $60-$ $\mathrm{ml}$ serum vials. All other media and reagents required for characterization tests were prepared as described by Holdeman et al. (3).

Isolation and stock culture maintenance. The inoculum used for isolation was obtained from a fermentor that was started by using a cellulose-enriched culture and was heated at $80^{\circ} \mathrm{C}$ for $10 \mathrm{~min}(8)$. The cellulolytic anaerobes present in this heat-treated culture survived repeated heating at $80^{\circ} \mathrm{C}$ for $10 \mathrm{~min}$. The inoculum was serially diluted in the basal medium. Each dilution $(0.1 \mathrm{ml})$ was disseminated onto a

\footnotetext{
* Corresponding author.

$\dagger$ Issued as National Research Council of Canada paper 23597.
}

filter paper placed over agar slants. For this purpose, the agar slants were prepared inside $160-\mathrm{ml}$ serum vials; any excess moisture present inside these vials was removed, and presterilized filter papers were placed over the slants. All of these procedures were carried out under an $\mathrm{N}_{2}-\mathrm{CO}_{2}$ atmosphere and aseptic conditions. This method was preferred over the conventional petri dish technique, as growth of these anaerobes depends on direct contact between them and the cellulose. After incubation for 4 to 7 days, the colonies were picked and transferred into broth basal medium containing tissue papers ( $2 \mathrm{~g} /$ liters). After complete dissolution of the tissue paper, the broth was serially diluted and plated onto an agar slant. This procedure was repeated three times. A stock culture of the isolate was maintained on basal medium containing tissue paper by transferring at 3- to 4-day intervals. Incubation was carried out at 35 to $37^{\circ} \mathrm{C}$ with shaking.

Biochemical tests and electron microscopy. Biochemical tests and substrate utilization tests were carried out in basal medium containing the desired substrate $(0.5$ or $1.0 \%$, wt/ vol) by using the procedures described by Holdeman et al. (3). Inoculated vials were incubated at $35^{\circ} \mathrm{C}$ and tested at 48 $h$ and 7-day intervals. All negative tests were held for 2 weeks. Analyses were made to determine gas volume and composition $\left(\mathrm{H}_{2}\right.$ and $\left.\mathrm{CO}_{2}\right)$, as well as volatile and nonvolatile acids and alcohols $(3,6)$. To determine the optimum $\mathrm{pH}$ for growth, the initial $\mathrm{pH}$ of the broth was adjusted in about $0.5-\mathrm{pH}$ unit increments between $\mathrm{pH} 5$ and 9 . Cells harvested from a 72-h-old cellobiose broth culture were used for extraction of deoxyribonucleic acid, and the guanine-pluscytosine content was determined as described by Marmur (11), Markov and Ivanov (10), and Ulitzur (17). For electron microscopy, cultures were grown in basal medium containing cellobiose as the sole carbon source and were incubated without shaking. Electron microscopy was carried out on 2and 4-day-old cultures as described previously (2). Gel electrophoresis of extracellular proteins was carried out by using the method of Wood (18).

\section{RESULTS AND DISCUSSION}

A new strain was isolated by serial dilution of heat-treated cellulose-enriched domestic sewage sludge streaked onto cellulose layered agar. On the basis of Gram straining, 


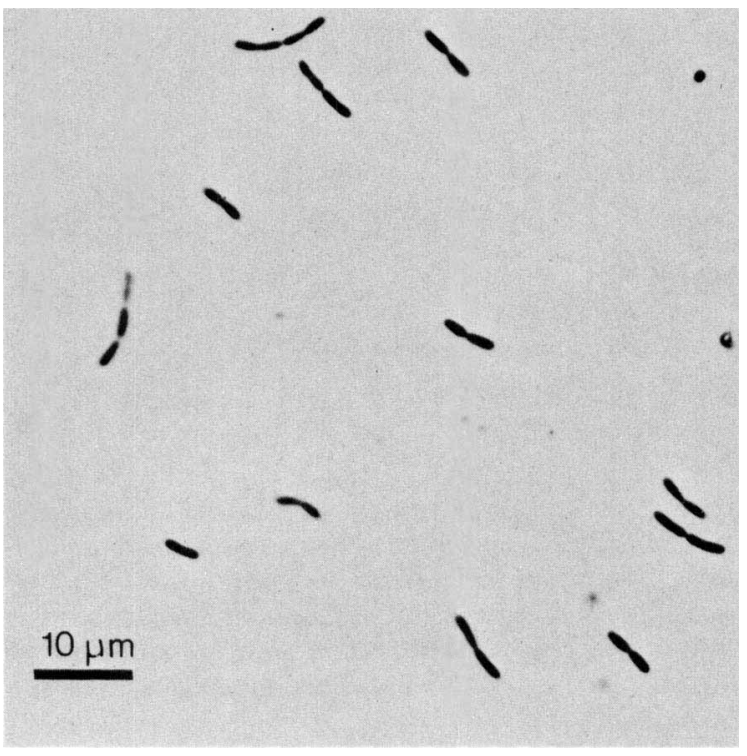

FIG. 1. Cell morphology of a culture grown in cellobiose broth

metabolic properties, and guanine-plus-cytosine content of the deoxyribonucleic acid, this obligately anaerobic rodshaped organism was assigned to the genus Acetivibrio (4, 12). The two species currently in this genus are motile by single or multiple flagella. Therefore, we emend the description of the genus Acetivibrio (14) to include nonmotile aflagellate species with cellular and metabolic properties similar to those of Acetivibrio cellulolyticus (15) and Acetivibrio ethanolgignens (16).

A description of $A$. cellulosolvens sp. nov. is given below.
Acetivibrio cellulosolvens sp. nov. Acetivibrio cellulosolvens (cel. lu. lo. sol. vens. L. verb solvere to dissolve; N.L. adj. cellulosolvens cellulose dissolving, indicating the ability of this organism to ferment cellulosic substrates) cells are obligately anaerobic, gram negative, rod shaped, and straight and occur singly, in pairs, or in chains of three or more cells (Fig. 1). Single cells are about 0.3 to 0.7 by 2 to 3 $\mu \mathrm{m}$. No spores have been detected, and 72-h- and 2-weekold cultures grown on cellobiose or cellulose medium fail to survive heating at $80^{\circ} \mathrm{C}$ for $10 \mathrm{~min}$ or exposure to $50 \%$ ethanol (9). The cells are nonmotile with no flagella visible in electron micrographs of young cells grown without shaking in broth containing cellobiose (Fig. 2). Electron micrographs show that one end of each cell is round and uniform and the other end is rough and uneven. This characteristic is observed in both young and old cells. The cells have an outer membrane (Fig. 3).

Colonies on cellulose agar are visible after 4 to 7 days of incubation. They are about 2 to $3 \mathrm{~mm}$ in diameter, entire, raised, and cream colored, showing no clear zones surrounding the colonies. Growth in cellulose-containing broth under an $\mathrm{N}_{2}-\mathrm{CO}_{2}$ gas phase has little or no color.

The optimum growth temperature is between 35 and $37^{\circ} \mathrm{C}$, and there is no growth at 20 or $45^{\circ} \mathrm{C}$. The optimum $\mathrm{pH}$ is between 6.5 and 7.5 , and there is no growth at $\mathrm{pH} 6.0$ or 8.0 .

Only cellulose, cellobiose, esculin, and salicin support growth. Yeast extract or rumen fluid is not required for growth on these carbon sources. Bile (2\% Oxgall; Difco) inhibits growth.

No growth is produced in medium supplemented with adonitol, amygdalin, arabinose, Casamino Acids, casein, chopped meat broth, dulcitol, erythritol, fructose, galactose, glucose, glycerol, glycogen, inositol, inulin, lactate, lactose, maltose, mannitol, mannose, melezitose, melibiose, milk, peptone, pyruvate, raffinose, rhamnose, ribose, sorbitol,

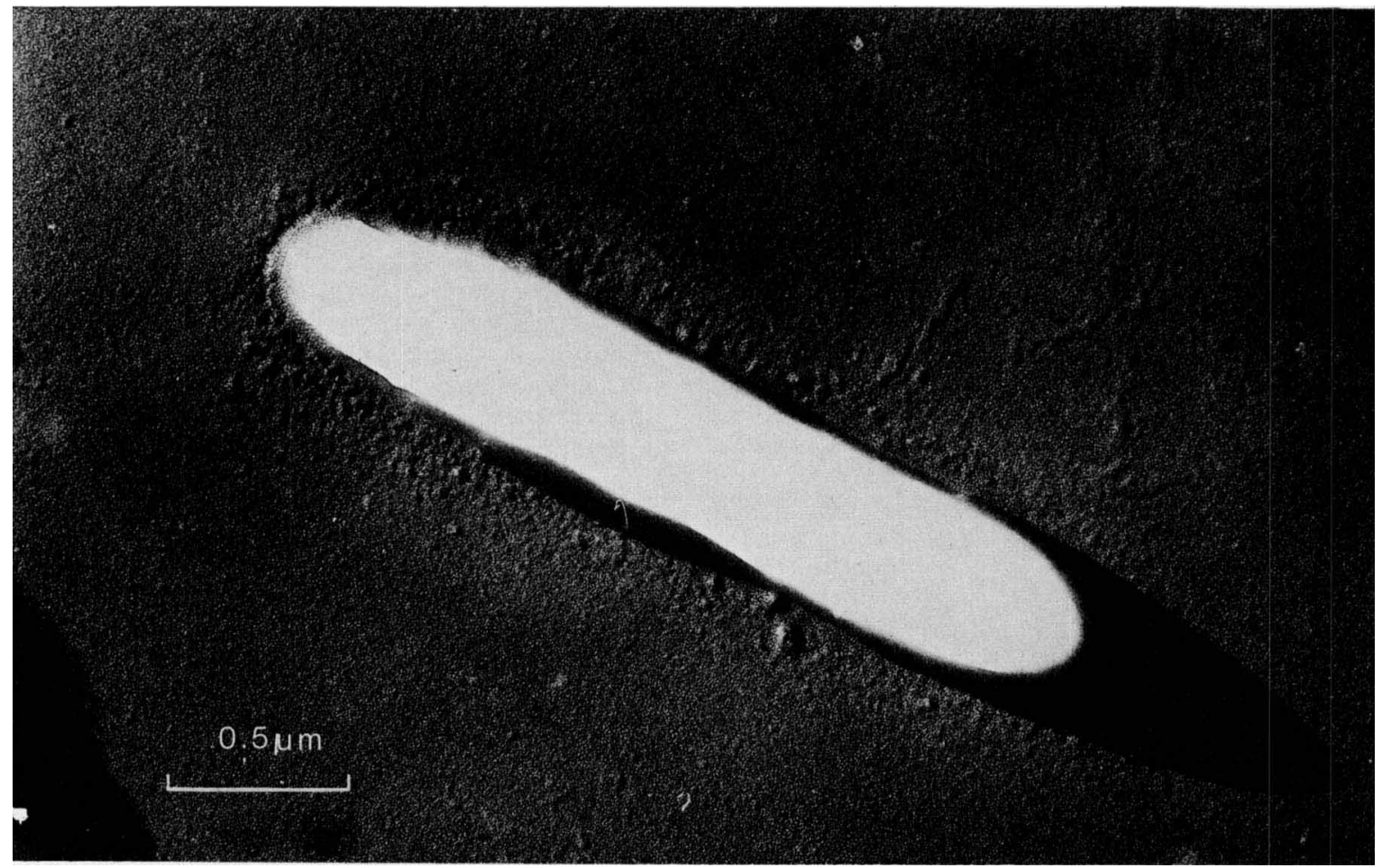

FIG. 2. Electron micrograph of a strain $\mathrm{BAS}^{\mathrm{T}}$ cell from a 2-day-old culture grown in cellobiose medium under stationary culture conditions. 


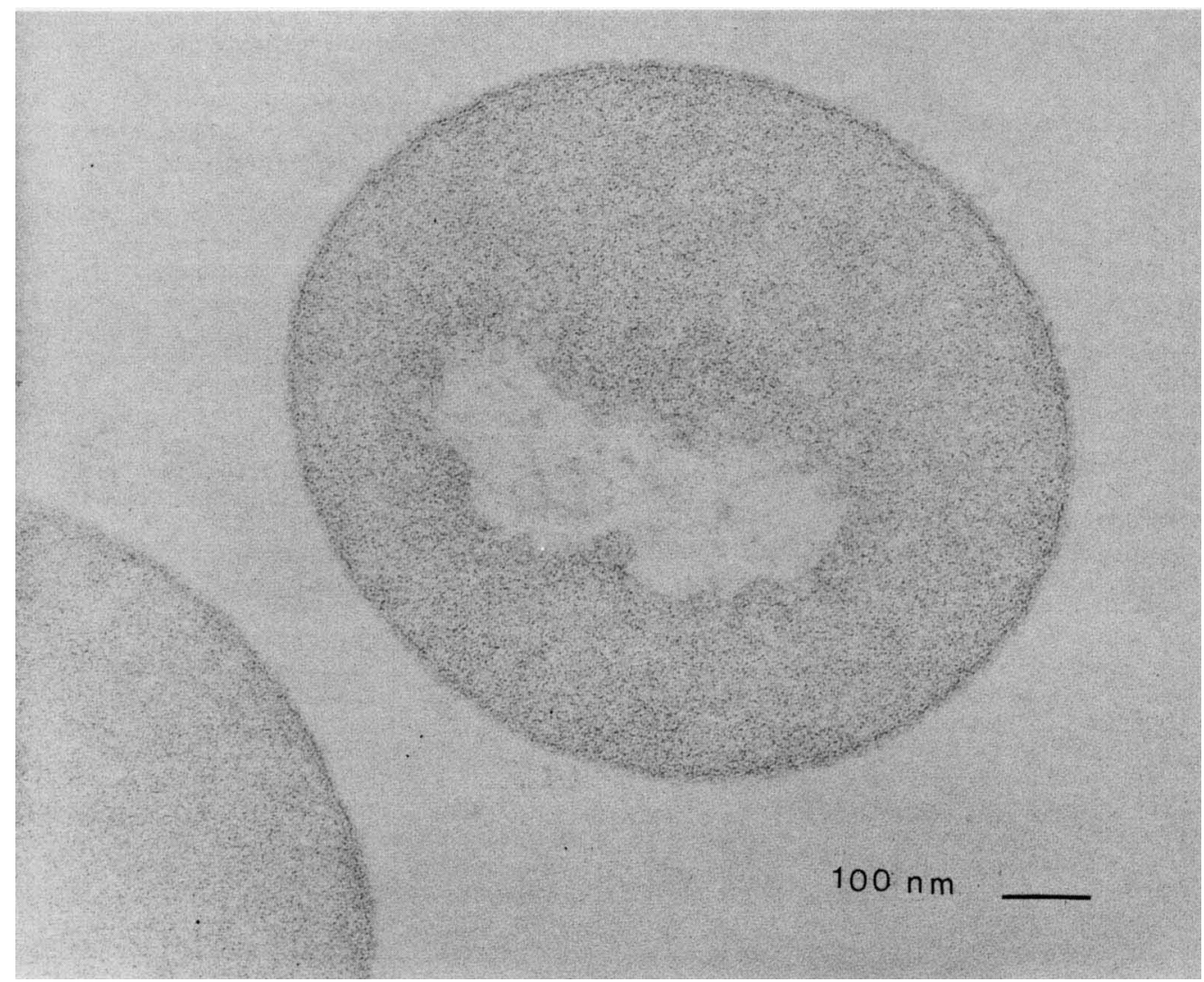

FIG. 3. Ultrastructure of strain $B A S^{\mathrm{T}}$, showing the outer membrane. Fixation was carried out by using the glutaraldehyde-osmium tetrachloride technique.

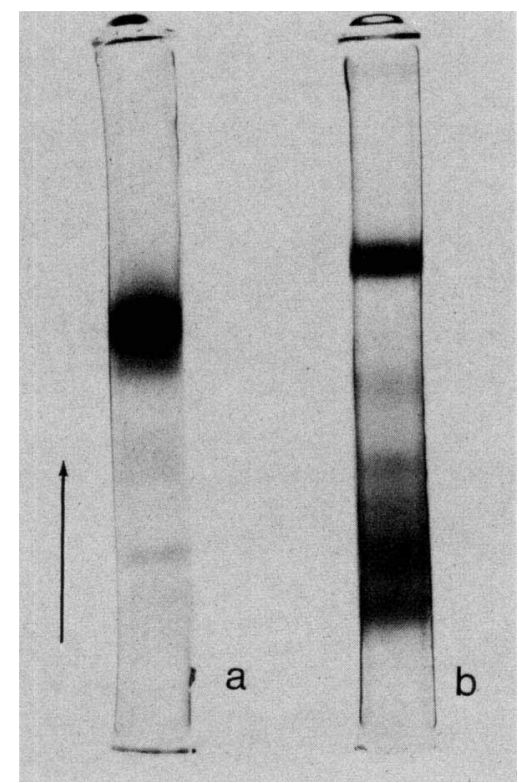

FIG. 4. Polyacrylamide gel electrophoretic analysis of extracellular cellulase proteins obtained from $A$. cellulosolvens (a) and $B$. cellulosolvens (b). sorbose, starch, sucrose, trehalose, urea, xylose, or yeast extract.

Esculin is hydrolyzed to give a positive reaction with ferric ammonium citrate. Sulfate is not reduced to sulfite, gelatin is not hydrolyzed, and catalase is not produced. Indole and nitrate reduction tests are negative.

The metabolic products of cultures in basal medium containing cellobiose incubated for 4 to 8 days under $100 \%$ $\mathrm{N}_{2}$ or $80 \% \mathrm{~N}_{2}-20 \% \mathrm{CO}_{2}$ are acetic acid (18 mM), ethanol (3 $\mathrm{mM}), \mathrm{CO}_{2}$, and $\mathrm{H}_{2}$. Trace amounts of lactic acid also are produced. In cellulose-containing medium, glucose $(8 \mathrm{mM})$ also is produced.

The deoxyribonucleic acid base composition of the type strain is $41 \pm 1.4 \mathrm{~mol} \%$ guanine plus cytosine $(n=4)$.

The type strain of $A$. cellulosolvens is strain BAS, which has been deposited in the National Research Council of Canada culture collection as strain NRC 2936.

$A$. cellulosolvens differs from $A$. cellulolyticus (15) and $A$. ethanolgignens (16) in that it is nonmotile, hydrolyzes esculin, and gives a positive reaction with ferric ammonium citrate. A. cellulosolvens differs from Bacteroides succinogenes (1), another cellulolytic anaerobe in the family Bacteroidaceae, in its ability to hydrolyze esculin, in producing $\mathrm{H}_{2}$, in not using glucose, and in not producing succinic acid. It differs from Bacteroids cellulosolvens (13) in not producing a bright yellow pigment in cellulose or cellobiose broth, 
in hydrolyzing esculin to give a positive reaction with ferric ammonium citrate, and in showing distinct differences in gel electrophoretic analyses of extracellular cellulase proteins (Fig. 4).

\section{LITERATURE CITED}

1. Bryant, M. P., and R. N. Doetsch. 1954. A study of actively cellulolytic rod-shaped bacteria of the bovine rumen. J. Dairy Sci. 37:1176-1183.

2. Colvin, J. R., L. C. Sowden, G. B. Patel, and A. W. Khan. 1982. The ultrastructure of Acetivibrio cellulolyticus, a recently isolated cellulolytic anaerobe. Curr. Microbiol. 7:13-17.

3. Holdeman, L. V., E. P. Cato, and W. E. C. Moore. 1977. Anaerobe laboratory manual, 4th ed. Anaerobe Laboratory, Virginia Polytechnic Institute and State University, Blacksburg.

4. Holdeman, L. V., R. W. Kelley, and W. E. C. Moore. 1984. Family 1. Bacteroidaceae Pribram 1933, p. 602-604. In N. R. Krieg and J. G. Holf (ed.), Bergey's manual of systematic bacteriology, vol. 1. The Williams \& Wilkins Co., Baltimore.

5. Hungate, R. E. 1950. The anaerobic mesophilic cellulolytic bacteria. Bacteriol. Rev. 14:1-49.

6. Khan, A. W., and T. M. Trottier. 1978. Effect of sulfurcontaining compounds on anaerobic degradation of cellulose to methane by mixed cultures obtained from sewage sludge. Appl. Environ. Microbiol. 35:1027-1034.

7. Khan, A. W., T. M. Trottier, G. B. Patel, and S. M. Martin. 1979. Nutrient requirement for the degradation of cellulose to methane by a mixed population of anaerobes. J. Gen. Microbiol. 112:365-372.

8. Khan, A. W., D. Wall, and L. van den Berg. 1981. Fermentative conversion of cellulose to acetic acid and cellulolytic enzyme production by a bacterial mixed culture obtained from sewage sludge. Appl. Environ. Microbiol. 41:1214-1218.
9. Koransky, J. R., S. D. Allen, and V. R. Dowell, Jr. 1978. Use of ethanol for selective isolation of spore-forming microorganisms. Appl. Environ. Microbiol. 35:762-765.

10. Markov, G. G., and I. G. Ivanov. 1974. Hydroxyapatite column chromatography in procedures for isolation of purified DNA. Anal. Biochem. 59:555-563.

11. Marmur, J. 1961. A procedure for the isolation of deoxyribonucleic acid from microorganisms. J. Mol. Biol. 3:208-218.

12. Moore, W. E. C., J. L. Johnson, and L. V. Holdeman. 1976. Emendation of Bacteroidaceae and Butyrivibrio and descriptions of Desulfomonas gen. nov. and ten new species in the genera Desulfomonas, Butyrivibrio, Eubacterium, Clostridium, and Ruminococcus. Int. J. Syst. Bacteriol. 26:238-252.

13. Murray, W. D., L. C. Sowden, and J. R. Colvin. 1984. Bacteroides cellulosolvens $\mathrm{sp}$. nov., a cellulolytic species from sewage sludge. Int. J. Syst. Bacteriol. 34:185-187.

14. Patel, G. B. 1984. Genus Acetivibrio, p. 658-661. In N. R. Krieg and J. G. Holt (ed.), Bergey's manual of systematic bacteriology, vol. 1. The Williams \& Wilkins Co., Baltimore.

15. Patel, G. B., A. W. Khan, B. J. Agnew, and J. R. Colvin. 1980. Isolation and characterization of an anaerobic, cellulolytic microorganism, Acetivibrio cellulolyticus gen. nov., sp. nov. Int. J. Syst. Bacteriol. 30:179-185.

16. Robinson, I. M., and A. E. Ritchie. 1981. Emendation of Acetivibrio and description of Acetivibrio ethanolgignens, a new species from the colons of pigs with dysentery. Int. J. Syst. Bacteriol. 31:333-338.

17. Ulitzur, S. 1972. Rapid determination of DNA base composition by ultraviolet spectroscopy. Biochim. Biophys. Acta 272:1-11.

18. Wood, W. A. 1981. Physical methods, p. 286-327. In P. Gerhardt, R. G. E. Murray, R. N. Costilow, E. W. Nester, W. A. Wood, N. R. Krieg, and G. B. Phillips (ed.), Manual of methods for general bacteriology. American Society for Microbiology, Washington, D.C. 